\title{
Measurement at Student Service Satisfaction Using Fuzzy Service Quality Method at Indramayu State Polytechnic
}

\author{
Ahmad Lubis Ghozal ${ }^{1 *}$, Budi Warsito ${ }^{2}$, Munengsih Sari Bunga ${ }^{1}$, Darsih Darsih ${ }^{1}$, Moh Ali \\ Fikri $^{1}$ \\ ${ }^{1}$ Department of Informatics, Indramayu State Polytechnic, West Java, Indonesia \\ ${ }^{2}$ Department of Statistics, Faculty of Science and Mathematics, Diponegoro University, Central Java, \\ Indonesia
}

\begin{abstract}
Providing satisfaction to students and preventing students from all campus facilities services is very important to improve the quality of higher education. Therefore, this study aims to build a system to measure student satisfaction with campus services using the fuzzy servqual method. The number of samples is 100 students. The measuring instrument used in the study was declared valid with a significance level of $5 \%$ or a $95 \%$ confidence level. The reliability test with the result of 0.746 means that the measuring instrument used has high mobility. Data processing is done by calculating the value of fuzzification, defuzzification, and calculating the value of GAP between students' perceptions and expectations. From the results of the fuzzy servqual gap ranking with 5 variables, it shows that empathy gets to level 1 with the smallest value of -0.74 . Level 2 is an assurance with a value of -0.85 ; then level 3 is reliability with a gap value of -0.89 , the 4 th position is the reaction force with a gap value of -0.97 , and the 5 th position is real with a value of -1.27 . The results obtained can help the Indramayu State Polytechnic in improving the performance and quality of service.
\end{abstract}

\section{Introduction}

An important factor in increasing progress in every aspect of the world is one of them, which is education [1]. In Indonesia, education is divided into several levels, and college is the final level of education based on Law Number 12 of 2012 on higher education. At present, the number of universities in Indonesia reaches 4,574.

Higher education as a community service institution in education has an important role as a vehicle to develop and shape its students into high-quality graduates ready in the face of competition in this modern era. Therefore, the quality of higher education needs to be observed to produce quality graduates. Higher education's internal quality assurance system is the plan, implementation, control, and development of high-quality standards consistently

*Corresponding author: alghoz@gmail.com 
and continuously to obtain stakeholder satisfaction and graduate quality assurance following assigned competencies $[2,3]$.

One of the ways to compete, every college is required to be able to develop and improve its quality. Improving the quality is the right strategy to achieve an international scale college or a World Class University. Higher education services can be rated good and quality based on the good achievements of teaching staff, administrative staff and existing facilities. To provide a level of satisfaction to the number of students with the services provided and in accordance with what students expect to improve the quality of campus services.

The problem is the choice of the university to provide services for students such as adequate internet access, good computer labs, a comfortable library and a complete collection of books, comfortable and safe vehicles and other services, in order to provide something profitable for the campus, in this case providing satisfaction for students as well as free student dissatisfaction on all campus facility services [4]. Measuring the level of student satisfaction with the service becomes important and must be done by the university.

Satisfaction level analysis has been done by several researchers the world, one of the successes is to measure the satisfaction level of e-learning services using fuzzy servqual at Universiti Pendidikan Indonesia with 21 respondents obtained a gap value of -1.584 with a perceived value of 7.695 and an expectation of 9.277 [5]. Analysis of the quality level of outpatients in PUSKESMAS Baktiya using the fuzzy-servqual method has been successfully done with a value of 5.5. The results of defuzzification can be seen from the expected value of the quality of outpatient services [6]. Fuzzy Service Quality has been implemented to measure student service satisfaction at Universiti Dian Nuswantoro Semarang. The results of the overall gap calculation show a negative gap value with the meaning that the perception or service that users do not meet student expectations [1].

The success and success of fuzzy servqual in solving the satisfaction with the service are very appropriate if implemented at the Indramayu State Polytechnic. Indramayu State Polytechnic is the only polytechnic in region III of Cirebon. The number of students of 1,229 in the academic year 2019/2020 is based on the emergence of questions about the quality of campus services provided by the campus is in line with what is promised to students.

\section{Materials and Methods}

\subsection{Materials}

The research took place at Indramayu State Polytechnic, West Java, Indonesia. The study material used a web-based information system. Development system on a virtual private server with the domain http://kpm.polindra.ac.id. With web-based technologies that can be reached to all networks, the data collection process becomes faster and more effective. Measuring material in the form of a questionnaire for Indramayu state polytechnic students.

Data collection using sampling techniques to students from 3 (three) departments at Indramayu State Polytechnic. Sampling in empirical research is defined as the process of selecting or determining a sample (samples). Conventionally, the concept of a sample refers to a section of the population. The number of respondents of the study used was 100 students from 3 majors. The following are the measuring instruments used in the questionnaire: 
Table 2. Questionnaire Measurement Tool.

\begin{tabular}{|c|l|}
\hline \multicolumn{1}{|c|}{ No. } & \multicolumn{2}{|c|}{ Question Attributes } \\
\hline Tangible \\
\hline 1 & Comfort, cleanliness and safety of the college board \\
\hline 2 & Completeness, comfort, maximum cleanliness \\
\hline 3 & Completeness, comfort, cleanliness of the library \\
\hline 4 & Completeness, comfort, cleanliness and ease of exercise \\
\hline 5 & Comfort, cleanliness and availability of a train location \\
\hline 6 & Comfort, cleanliness, completeness and safety of the Student Activity Unit cubicles \\
\hline 7 & Hotspot broadband availability \\
\hline 8 & Comfort, cleanliness and safety of the prayer room (mosque) \\
\hline 9 & $\begin{array}{l}\text { The comfort, completeness, cleanliness and safety of the room await during class } \\
\text { breaks }\end{array}$ \\
\hline 10 & Availability of Green Areas \\
\hline 11 & Comfort, completeness, and safety of campus operating vehicles \\
\hline 12 & Comfort, completeness and cleanliness of the Tandas-WC room \\
\hline Reliability \\
\hline 13 & Curriculum and learning process \\
\hline 14 & Quality and eligibility Lecturer \\
\hline 15 & Lecture and practicum atmosphere \\
\hline 16 & The material presented by the penyarah was clear and pleased to be understood \\
\hline 17 & Alumni quality \\
\hline Responsiveness \\
\hline 18 & Respect and appropriateness in reverence \\
\hline 19 & The overall quality of service in supporting the smooth running of college activities \\
\hline 20 & $\begin{array}{l}\text { Conformity, Accuracy and Accuracy of SIAKAD Period (Academic Information } \\
\text { System) }\end{array}$ \\
\hline Assurance \\
\hline 21 & Knowledge and skills acquired after college \\
\hline 22 & Mastery of the field of work \\
\hline 23 & Campus safety \\
\hline 24 & Initiative in helping \\
\hline 25 & Hospitality, courtesy and attitude in serving \\
\hline
\end{tabular}

The instrument used to measure service quality was a written questionnaire or list of questions (statements) distributed to users, using a Likert scale. There are usually several types of Likert scales used, namely:

Table 3. Likert scale.

\begin{tabular}{|c|l|l|}
\hline Scale & \multicolumn{1}{|c|}{ Perception } & \multicolumn{1}{c|}{ Expectation } \\
\hline 1 & Very Dissatisfied & Very unimportant \\
\hline 2 & Dissatisfied & Not too important \\
\hline 3 & Quite satisfied & Quite important \\
\hline 4 & Satisfied & Important \\
\hline 5 & Very satisfied & Very important \\
\hline
\end{tabular}


The Likert perception scale provides information on the respondents 'state of satisfaction with the measured questions. Meanwhile, the Likert expectation scale provides information on respondents 'satisfaction expectations with the measured questions.

\subsection{Methods}

\subsubsection{Service Quality (Servqual)}

Service quality can be interpreted as a comparison between customer trust and service perception. The SERVQUAL model developed by Parasuraman et al. (1985) is one of the most widely used service quality measurement models to identify the gap between customers and service providers6. In the SERVQUAL model, there are five dimensions of service quality that include aspects of tangibles, reliability, responsiveness, assurance, and empathy. An explanation of the five dimensions can be seen in table 4 [7].

Table 4. Explanation of Servqual dimensions.

\begin{tabular}{|l|l|}
\hline \multicolumn{1}{|c|}{ Dimension } & \multicolumn{1}{c|}{ Explanation of dimensions } \\
\hline Tangible & The ability to display physical facilities and infrastructure \\
\hline Reliability & The ability to provide services as promised accurately and reliably \\
\hline Responsiveness & Willingness to help and provide fast and appropriate service to customers \\
\hline Assurance & The ability of service providers to grow the trust of customers \\
\hline Empathy & Give personal attention and understand the desires of customers \\
\hline
\end{tabular}

\subsubsection{Fuzzy}

Fuzzy Fuzzy set theory is a mathematical framework used to represent uncertainty, ambiguity, uncertainty, lack of information, and partial truth [8]. Lack of information in problem-solving is often found in various areas of life. Discussions about ambiguity have been going on since 1937, when a philosopher named Max Black put forward his opinion on ambiguity.

Convert the scale value to a fuzzy number from the input variable for each attribute as in table 3. Here are the steps to solve the servqual fuzzy algorithm: [9,10]

Step 1: Determine the fuzzy set for the linguistic variables and measurement scale.

In this step, each value given by the respondent in the questionnaire for each attribute will be calculated. Calculations are made on perceptions and expectations. The calculation is done using the following equation:

$A_{1}+A_{2}=\left(a_{1}+a_{2}, b_{1}+b_{2}, c_{1}+c_{2}\right)$

Step 2: Determine the fuzzy set for the linguistic variables and measurement scale In identifying user perceptions and expectations, linguistic variables are used. The measurement scale used is as shown in table 5.

Table 5. TFN Fuzzy Servqual.

\begin{tabular}{|c|l|l|}
\hline TFN & \multicolumn{1}{|c|}{ Perception } & \multicolumn{1}{c|}{ Expectation } \\
\hline $1,1,2$ & Very Dissatisfied & Very unimportant \\
\hline $1,2,3$ & Dissatisfied & Not too important \\
\hline $2,3,4$ & Quite satisfied & Quite important \\
\hline $3,4,5$ & Satisfied & Important \\
\hline $4,6,6$ & Very satisfied & Very important \\
\hline
\end{tabular}


Step 3: Establishment of TFN value perceptions and value of user expectations

The fuzzy calculation process is performed to form the TFN of the perceived value and the expected value of the user. Calculation to get the average weight of all users using the arithmetic mean with the following equation:

$$
\begin{aligned}
a_{m} & =\frac{\left(a_{m 1}+a_{m 2}+a_{m 3} \ldots \ldots a_{m i}\right)}{N} \\
b_{m} & =\frac{\left(b_{m 1}+b_{m 2}+b_{m 3} \ldots . . b_{m i}\right)}{N} \\
c_{m} & =\frac{\left(c+c_{m 2}+c_{m 3} \ldots c_{m i}\right)}{N}
\end{aligned}
$$

\section{Step 4: Get a single value from the average weight of each variable}

The next step confirms the fuzzification value obtained using the defuzzification calculation. The result of defuzzification will be the single value of the average weight of each variable. The defuzzification stage uses the following equation:

$$
X=\frac{a_{m}+b_{m}+c_{m}}{3}
$$

\section{Step 5: Calculate the gap for each attribute}

The role of each attribute gap will show how important these attributes are in providing improved service quality. After getting the defuzzification value for perception and defuzzification for expectation, the gap for each attribute can be calculated using the following equation.

$$
\operatorname{Gap}_{i}=M A_{p i}-M A_{e i}
$$

\section{Implementation}

The fuzzy servqual application to determine student satisfaction with campus services was performed by testing questionnaires with validity and reliability tests. The total number of respondents was 100 students with table $\mathrm{r}-0.195$. Table $\mathrm{R}$ is a table of numbers commonly used to test the test results of the validity of study instruments.

Table 6. Instrument Validity Test.

\begin{tabular}{|l|l|l|l|l|l|}
\hline \multicolumn{3}{|c|}{ Perception } & \multicolumn{3}{c|}{ Expectation } \\
\hline \multicolumn{3}{|c|}{-table 0.195le 0.195 } \\
\hline P1 & 0.606 & Valid & H1 & 0.386 & Valid \\
\hline P2 & 0.570 & Valid & H2 & 0.396 & Valid \\
\hline P3 & 0.492 & Valid & H3 & 0.405 & Valid \\
\hline P4 & 0.510 & Valid & H4 & 0.353 & Valid \\
\hline P5 & 0.519 & Valid & H5 & 0.421 & Valid \\
\hline P6 & 0.615 & Valid & H6 & 0.440 & Valid \\
\hline P7 & 0.577 & Valid & H7 & 0.335 & Valid \\
\hline P8 & 0.464 & Valid & H8 & 0.492 & Valid \\
\hline P9 & 0.671 & Valid & H9 & 0.449 & Valid \\
\hline P10 & 0.581 & Valid & H10 & 0.333 & Valid \\
\hline P11 & 0.560 & Valid & H11 & 0.359 & Valid \\
\hline P12 & 0.534 & Valid & H12 & 0.474 & Valid \\
\hline
\end{tabular}




\begin{tabular}{|l|l|l|l|l|l|}
\hline \multicolumn{3}{|c|}{ Perception } & \multicolumn{3}{c|}{ Expectation } \\
\hline \multicolumn{3}{|c|}{-table 0.195le 0.195 } \\
\hline P13 & 0.650 & Valid & H13 & 0.493 & Valid \\
\hline P14 & 0.564 & Valid & H14 & 0.536 & Valid \\
\hline P15 & 0.708 & Valid & H15 & 0.535 & Valid \\
\hline P16 & 0.639 & Valid & H16 & 0.524 & Valid \\
\hline P17 & 0.368 & Valid & H17 & 0.389 & Valid \\
\hline P18 & 0.674 & Valid & H18 & 0.481 & Valid \\
\hline P19 & 0.640 & Valid & H19 & 0.495 & Valid \\
\hline P20 & 0.670 & Valid & H20 & 0.624 & Valid \\
\hline P21 & 0.604 & Valid & H21 & 0.531 & Valid \\
\hline P22 & 0.511 & Valid & H22 & 0.479 & Valid \\
\hline P23 & 0.495 & Valid & H23 & 0.497 & Valid \\
\hline P24 & 0.432 & Valid & H24 & 0.582 & Valid \\
\hline P25 & 0.704 & Valid & H25 & 0.471 & Valid \\
\hline P26 & 0.524 & Valid & H26 & 0.501 & Valid \\
\hline
\end{tabular}

If we look at the diagram, at $d f$ or N 100 with a significance level of $5 \%$, the value of table $r$ is 0.195 . If the calculated value of $r>$ the value of $r$ of the table, then the item on the question instrument is said to be valid or there is a correlation between the linked variables. However, if the calculated value of $r$ is $<r$ table value, then the item on the instrument is invalid or this means that there is no relationship between the linked variables. This $R$ count was obtained from the test results with SPSS. The next step is a reliability test with results as shown in Table 7.

Table 7. Case Processing Summary.

\begin{tabular}{|l|l|r|r|}
\hline \multicolumn{2}{|c|}{} & \multicolumn{1}{|c|}{ N } & \multicolumn{1}{c|}{$\%$} \\
\hline \multirow{3}{*}{ Cases } & Valid & 100 & 100.0 \\
\cline { 2 - 4 } & Excluded $^{\mathrm{a}}$ & 0 &, 0 \\
\cline { 2 - 4 } & Total & 100 & 100.0 \\
\hline
\end{tabular}

Table 8. Reliability Statistics.

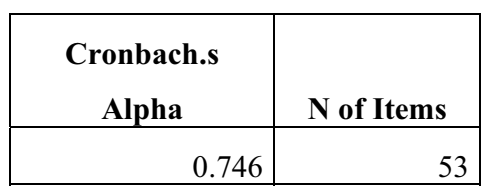

Reliability testing refers to the understanding that the instruments used in research to obtain the information used are reliable as data collection tools and can reveal real information in the field. Reliability testing is also a tool for measuring questionnaires that are indicators of variables or constructs. A questionnaire is said to be reliable or trustworthy if a person's answer to the statement is consistent or stable over time. The reliability test results of table 8 show that the measuring instrument used is of high reliability indicated by the value 
of rxx 0.746 close to the number 1 . In general, the reliability is considered satisfactory if $\geq$ 0.700 .

The characteristics of the respondents are Indramayu State Polytechnic students with a composition of 13 Departments of Informatics Engineering, 17 Departments of Mechanical Engineering and 70 Departments of Air Conditioning and Air Conditioning Engineering as shown in Figure 1.

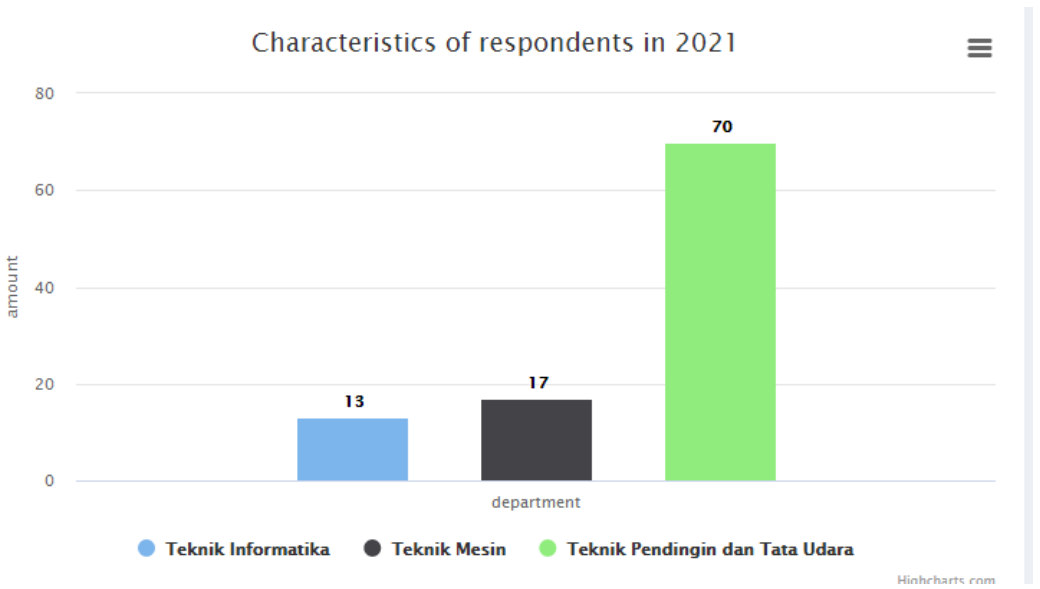

Fig. 1. Characteristics of Respondents.

The next step is to calculate the number of answers on the respondents' Likert scale based on equation 1. The results of the calculation of perceptions and expectations are shown in table 9.

Table 9. Number of respondents based on Likert scale.

\begin{tabular}{|c|l|c|c|c|c|c|c|c|c|c|c|}
\hline \multirow{2}{*}{ No Question } & \multicolumn{3}{|c|}{ Perception } & \multicolumn{4}{|c|}{ Expectation } \\
\cline { 3 - 10 } & & $\mathbf{1}$ & $\mathbf{2}$ & $\mathbf{3}$ & $\mathbf{4}$ & $\mathbf{5}$ & $\mathbf{1}$ & $\mathbf{2}$ & $\mathbf{3}$ & $\mathbf{4}$ & $\mathbf{5}$ \\
\hline 1 & Comfort, cleanliness and safety of the college board & 2 & 26 & 26 & 39 & 7 & 1 & 0 & 8 & 23 & 68 \\
\hline 2 & Completeness, comfort, maximum cleanliness & 1 & 27 & 26 & 34 & 12 & 0 & 0 & 10 & 17 & 73 \\
\hline 3 & Completeness, comfort, cleanliness of the library & 0 & 8 & 31 & 45 & 16 & 0 & 1 & 13 & 25 & 61 \\
\hline 4 & $\begin{array}{l}\text { Completeness, comfort, cleanliness and ease of } \\
\text { exercise }\end{array}$ & 25 & 30 & 20 & 21 & 4 & 1 & 2 & 15 & 35 & 47 \\
\hline 5 & Comfort, cleanliness and availability of a train location & 8 & 32 & 22 & 28 & 10 & 0 & 0 & 11 & 27 & 62 \\
\hline 6 & $\begin{array}{l}\text { Comfort, cleanliness, completeness and safety of the } \\
\text { Student Activity Unit cubicles }\end{array}$ & 11 & 26 & 26 & 32 & 5 & 0 & 0 & 13 & 24 & 63 \\
\hline 7 & Hotspot broadband availability & 8 & 36 & 22 & 26 & 8 & 0 & 0 & 9 & 12 & 79 \\
\hline 8 & $\begin{array}{l}\text { Comfort, cleanliness and safety of the prayer room } \\
\text { (mosque) }\end{array}$ & 1 & 16 & 19 & 49 & 15 & 0 & 0 & 6 & 17 & 77 \\
\hline 9 & $\begin{array}{l}\text { The comfort, completeness, cleanliness and safety of } \\
\text { the room await during class breaks }\end{array}$ & 13 & 30 & 24 & 28 & 5 & 0 & 0 & 13 & 28 & 59 \\
\hline 10 & Availability of Green Areas & 18 & 37 & 19 & 20 & 6 & 0 & 1 & 10 & 18 & 71 \\
\hline 11 & $\begin{array}{l}\text { Comfort, completeness, and safety of campus } \\
\text { operating vehicles }\end{array}$ & 14 & 25 & 22 & 33 & 6 & 0 & 1 & 13 & 31 & 55 \\
\hline 12 & $\begin{array}{l}\text { Comfort, completeness and cleanliness of the Tandas- } \\
\text { WC room }\end{array}$ & 12 & 26 & 29 & 25 & 8 & 0 & 0 & 14 & 19 & 67 \\
\hline 13 & Curriculum and learning process & 2 & 17 & 21 & 54 & 6 & 0 & 0 & 7 & 20 & 73 \\
\hline 14 & Quality and eligibility Lecturer & 0 & 10 & 29 & 52 & 9 & 0 & 0 & 8 & 18 & 74 \\
\hline 15 & Lecture and practicum atmosphere & 1 & 13 & 27 & 47 & 12 & 0 & 0 & 10 & 19 & 71 \\
\hline 16 & $\begin{array}{l}\text { The material presented by the penyarah was clear and } \\
\text { pleased to be understood }\end{array}$ & 0 & 16 & 38 & 38 & 8 & 0 & 0 & 9 & 16 & 75 \\
\hline 17 & Alumni quality & 2 & 11 & 34 & 43 & 10 & 1 & 1 & 17 & 21 & 60 \\
\hline 18 & Respect and appropriateness in reverence & 22 & 24 & 38 & 9 & 0 & 0 & 9 & 29 & 62 \\
\hline
\end{tabular}




\begin{tabular}{|c|c|c|c|c|c|c|c|c|c|c|c|}
\hline \multirow{2}{*}{ No } & \multirow{2}{*}{ Question } & \multicolumn{5}{|c|}{ Perception } & \multicolumn{5}{|c|}{ Expectation } \\
\hline & & 1 & 2 & 3 & 4 & 5 & 1 & 2 & 3 & 4 & 5 \\
\hline 19 & $\begin{array}{l}\text { The overall quality of service in supporting the smooth } \\
\text { running of college activities }\end{array}$ & 3 & 11 & 36 & 40 & 10 & 0 & 0 & 14 & 25 & 61 \\
\hline 20 & $\begin{array}{l}\text { Conformity, Accuracy and Accuracy of SIAKAD } \\
\text { Period (Academic Information System) }\end{array}$ & 2 & 12 & 40 & 38 & 8 & 0 & 0 & 12 & 26 & 62 \\
\hline 21 & Knowledge and skills acquired after college & 0 & 16 & 25 & 50 & 9 & 0 & 0 & 10 & 17 & 73 \\
\hline 22 & Mastery of the field of work & 1 & 14 & 28 & 49 & 8 & 0 & 0 & 10 & 19 & 71 \\
\hline 23 & Campus safety & 3 & 8 & 22 & 47 & 20 & 0 & 0 & 8 & 16 & 76 \\
\hline 24 & Initiative in helping & 4 & 8 & 30 & 44 & 14 & 0 & 0 & 13 & 25 & 62 \\
\hline 25 & Hospitality, courtesy and attitude in serving & 1 & 10 & 27 & 49 & 13 & 0 & 0 & 10 & 26 & 64 \\
\hline 26 & $\begin{array}{l}\text { Good communication between students and positions } \\
\text { is established }\end{array}$ & 2 & 9 & 24 & 43 & 22 & 0 & 0 & 8 & 18 & 74 \\
\hline & Number of respondents & \multicolumn{10}{|c|}{100} \\
\hline
\end{tabular}

Table 9 provides information that question number 1 respondents answered the perception of Likert scale 1, which is 11 students, Likert scale 2 is 26 students, Likert scale 3 is 26 students, Likert scale 4 is 32 students and Likert scale 5 is 5 students. While question number 1, respondents answered the expectation of Likert scale 1, which is 0 students, Likert scale 2 is 0 students, Likert scale 3 is 13 students, Likert scale 4 is 24 students and Likert scale 5 is 63 students.

Table 10. Student Satisfaction Defuzzification.

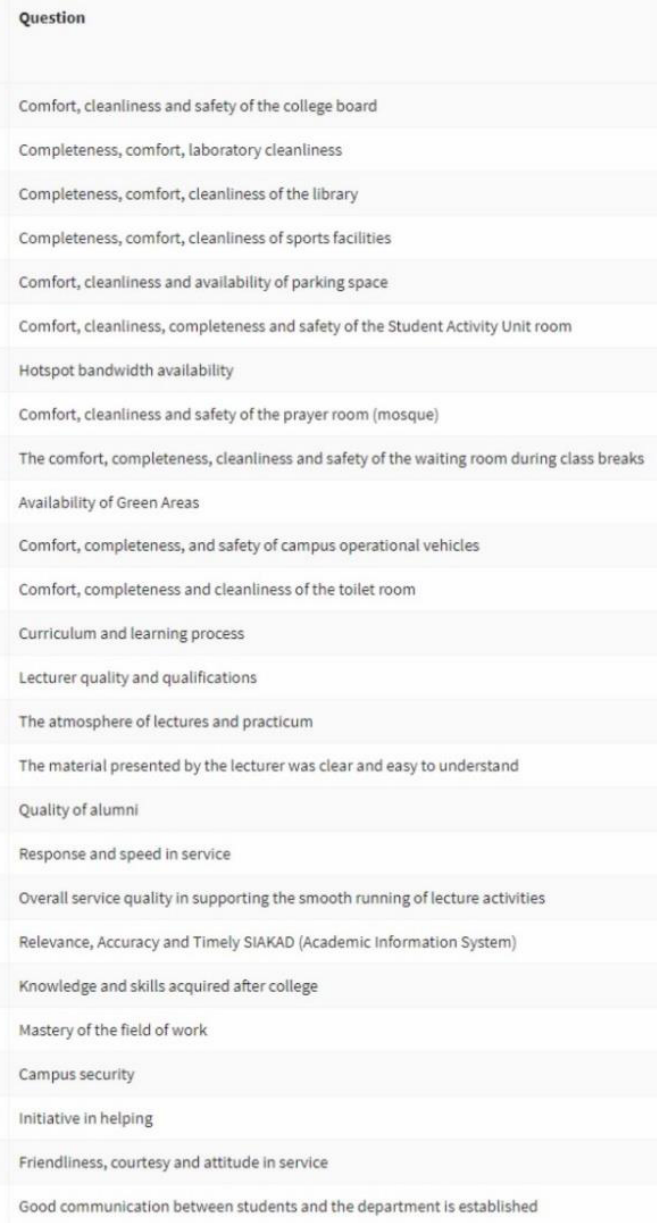


After knowing the result of the respondent's Likert scale, the next step is to calculate the fuzzy by applying equations 2 and 3 so as to produce the value of deflux education perception $(X \mathrm{p})$ and defluxification perception $(X \mathrm{p})$, as shown in Figure 2. value a is a low fuzzy number, $\mathrm{b}$ is the medium fuzzy number, and $\mathrm{c}$ is the upper fuzzy number. The defufation value of each perception and expectation will then calculate the performance gap through equation 5 and produce figure 2 .

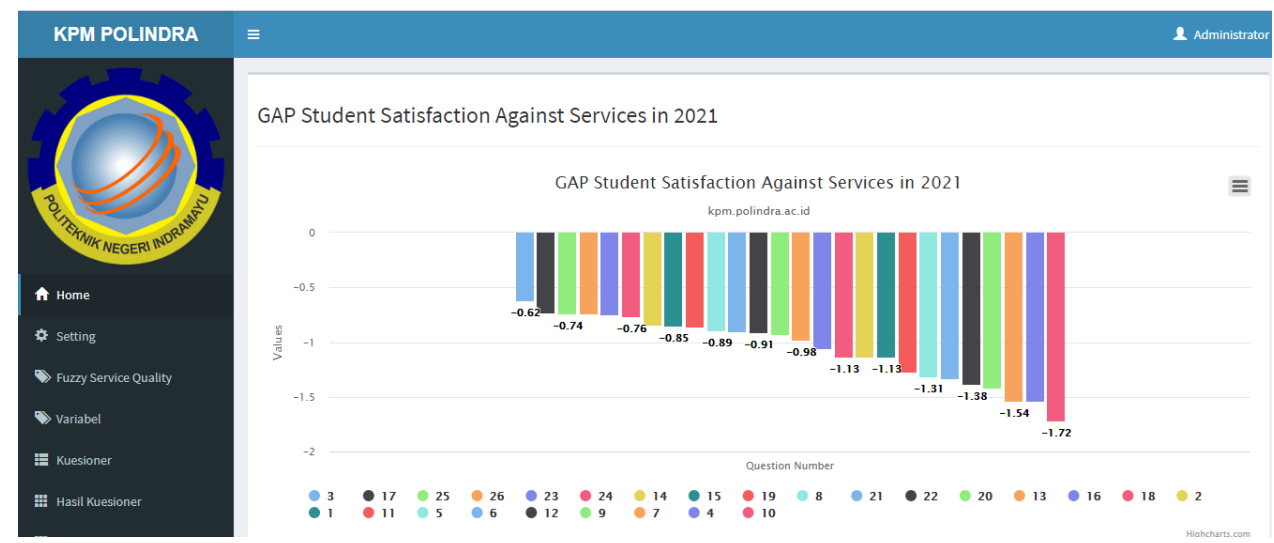

Fig. 2. GAP Student Satisfaction Against Services in 2021.

The results of the application of gap performance analysis provide information by means of graphic pictures in accordance with the ranking obtained through equation 5. Position 1 (first) with the smallest gap value shows in question number 3, which is -0.63 . In comparison, the largest gap value is question number 10, which is -1.72 . The values obtained from the respondents are all reduced, indicating that each student's satisfaction with the campus services is still beyond expectations, with measures necessary to improve management for the total number of gaps that occur between students and campus.

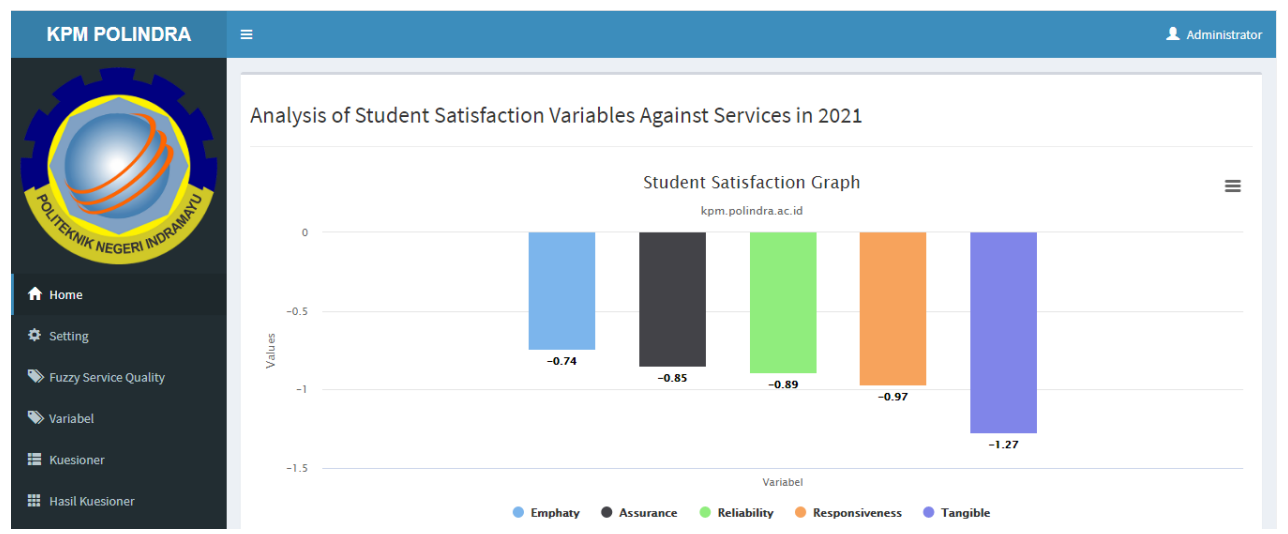

Fig. 3. Analysis of Student Satisfaction Variables Against Services in 2021.

The fuzzy servqual gap level with 5 variables indicates that emphaty gets position 1 with the smallest value, i.e. -0.74 , then the 2 nd level is assurance with a value of -0.85 , then the 3 rd level is reliability with a gap value of -0.89 , the 3 rd level is 4 is responsive with a gap value of -0.97 and the 5 th stage is real with a value of -1.27 The detailed position can be seen in table 11 . 
Table 11. Table Ranking of Student Satisfaction Variables Against Service in 2021.

\begin{tabular}{|c|c|c|c|c|c|}
\hline Rank & Variable & Perception & Expectation & GAP & Explanation \\
\hline 1 & Emphaty & 3.60 & 4.34 & -0.74 & Needs improvement \\
\hline 2 & Assurance & 3.54 & 4.40 & -0.85 & Needs improvement \\
\hline 3 & Reliability & 3.47 & 4.36 & -0.89 & Needs improvement \\
\hline 4 & Responsiveness & 3.32 & 4.29 & -0.97 & Needs improvement \\
\hline 5 & Tangible & 3.04 & 4.31 & -1.27 & Needs improvement \\
\hline
\end{tabular}

The stage provides information that the management of Indramayu State Polytechnic must improve management so that there is no minus value. Especially for a real variable that gets a gap value of -1.27 .

\section{Result and Discussion}

The questionnaire as a measuring tool used in the study was declared valid with a significance level of $5 \%$ or a confidence level of $95 \%$. In addition, the questionnaire was tested for its reliability with a result of 0.746 , and thus the measuring instrument used had high mobility as it was above 0.700 .

The analysis of student satisfaction with the service using the fuzzy servqual method obtained the value of the minus gap until the management of the Indramayu State Polytechnic campus is treated with better management improvement. By obtaining the value of the gap from this study, management can read the state of campus services to students to facilitate decision-making.

The fuzzy servqual gap level with 5 variables indicates that empathy gets position 1 with the smallest value, i.e. -0.74 , then the 2 nd level is an assurance with a value of -0.85 . The $3 \mathrm{rd}$ level is reliability with a gap value of -0.89 ; the 3 rd level is 4 is the reaction force with a gap value of -0.97 , and the 5 th stage is real with a value of -1.27 .

\section{References}

1. N. F. Kartika and . S., Sisfotenika 7, 38 (2017)

2. $\quad$ M. Ali Fikri, R. Gernowo, and B. Surarso, in E3S Web Conf. (2020)

3. F. E. Daromes and S. Ng, Procedia - Soc. Behav. Sci. 211, 660 (2015)

4. R. S. Hariady Turnip, Marihat Situmorang, Saintia Mat. 2, 163 (2014)

5. A. R. Prayudha, S. Sumarto, and A. G. Abdullah, IOP Conf. Ser. Mater. Sci. Eng. 830, (2020)

6. Bakhtiar, M. Zakaria, K. Anshar, and F. Wahyuni, IOP Conf. Ser. Mater. Sci. Eng. 1003, (2020)

7. S. Miranda, P. Tavares, and R. Queiró, J. Bus. Res. 89, 371 (2018)

8. B. R. Smith, 519 (1983)

9. R. Liu, L. Cui, G. Zeng, H. Wu, C. Wang, S. Yan, and B. Yan, Appl. Soft Comput. J. 26, 508 (2015)

10. I. Firdaus, Farikhin, and B. Surarso, E3S Web Conf. 202, (2020) 